\title{
The effects of quality control system on professional skepticism and its implications to audit quality with peer review as a moderating variable (A case study on Public Accounting Firms in Semarang)
}

\author{
Hafidz Ridloi \\ Universitas Islam Negeri Walisongo Semarang, Indonesia \\ email: hafidzridloi007@gmail.com
}

\begin{abstract}
Purpose - This study aims to assess the role of CPA Firms related to the quality control system in maintaining the professional skepticism level of auditors affecting the quality of audits provided by the Public Accountants.
\end{abstract}

Method - Population and samples used in this research were the whole auditors working for the CPA Firms in Semarang. The researcher collected the samples using a purposive sampling technique. The number of samples in this study was 31 auditors. The researcher collected the data using online questionnaires sent through email to each CPA Firm. Data analysis was conducted using a Structural Equation Modeling - Partial Least Square (SEM-PLS) with WarpPLS 4.0 software.

Result - The results of this study indicated that the quality control system did not affect the auditor's professional skepticism. Peer review did not moderate the quality control system. The auditor's professional skepticism variable has a significant effect on audit quality. Then, quality control system did not affect audit quality through auditor's professional skepticism.

Implication - To maintain audit quality, CPA Firms in Semarang needs to improve the competence, experience, and professionalism of auditors performing the audit assignments that the professional skepticism of the concerned personnel can be properly maintained.

Originality - This study has presented a moderating variable in the relationship between peer review and quality control system affecting professional skepticism.

Keywords: quality control system; professional skepticism; audit quality; peer review 
Hafidz Ridloi

\section{Introduction}

All companies, especially go-public companies, have to make financial reports for the stakeholders. The financial statements published are reports

JIAFR | 76 passing the audit process to obtain opinions that those reports are free from the material misstatement influencing the economic decisions (Agriyanto et al., 2016). Thus, many parties rely and base their decisions on the results of audited financial statements certified by the public accountants, as the audit service providers, who must keep the trust by considering the audit quality level (Junusi, 2020).

To meet the needs for the audit quality results, the Indonesian Institute of Certified Public Accountants as an organization hosting the public accounting profession has established the Public Accountant Professional Standards (known as PAPS). PAPS are standard references, guidelines, and rules in performing the audit procedures followed and applied by the auditors in performing the audit processes.

As professionals, auditors must always be responsible for upholding the professional attitude by performing the audit processes in accordance with the Public Accounting Professional Standards (PAPS) and maintaining the quality and image of the public accountant profession. To use the auditor's professional competences, the auditor should indirectly apply the professional skepticism during the audit processes. The auditor professional skepticism is an attitude including an idea which always questions and evaluates the audit evidence skeptically.

Since many parties have trusted the audit results provided by the auditor, the Financial Professional Development Center under the Ministry of Finance, as an institution granting the licenses to Public Accounting Firms and Public Accountants, has conducted a periodic monitoring and evaluation related to the implementation of standards and applicable codes of ethics as stated in the Minister of Finance Regulation Number 17/PMK.01/2008 on Public Accountant Services. 
According to the peer reviews, the data taken from the Financial Professional Development Center of the Ministry of Finance in 2017, KAPs were generally sufficient to comply with the Quality Control Standard 1 (QCS 1), out of 77 KAPs examined in 2017. There were 53 KAPs or 69\% which have not fully complied with the QCS 1 . There were 167 findings of noncompliance with the QCS 1 comprising the findings on the design and implementation of 20 out of 147 findings.

These non-compliance results will indirectly impact the audit quality decline. If not immediately fixed, it will certainly reduce the public trust to the accounting profession and also reduce the credibility of Public Accountants for the results of their audits. The results of research conducted by Renianawati et al., (2016) state that quality control system has a significant effect on audit quality.

In addition, there is another factor called the auditors' reduced professional skepticism as not implementing a good quality control system (CNN Indonesia, 2018). Ananda (2014) explained that the public accountants' skepticism has a significant effect on the audit quality results. However, there is no research stating that weak quality control system implemented by the Public Accounting Firm can reduce the auditors' professional skepticism.

Based on the data obtained from the Directory of Public Accounting Firms (2020) issued by the Indonesian Institute of Public Accountants (known as IAPI/Ikatan Akuntan Publik Indonesia), there are 28 KAPs in Semarang. 12 or $43 \%$ of KAPs have just obtained permits in the period of 2017 - 2019. It needs a special attention from the regulators regarding to how the new KAP implements a quality control system in accordance with the applicable regulations. Thus, this study focused on the application of a quality control system in its function as the audit quality control at the public accounting firms in Semarang. 
Hafidz Ridloi

\section{Literature Review}

\section{Audit Quality}

JIAFR | 78

According to De Angelo in Bustami (2013), audit quality is all possibilities where the public accountants, when performing the audit processes of the client's financial statements, can determine or find violations occurring in the accounting system and report these findings in the audited financial reports, where in the implementation audit procedures, public accountants must be guided by the applicable and relevant auditing standards and codes of conduct.

\section{Quality Control System}

Quality control system is a concept requiring public accounting firms to comply with the applicable regulations and standards (Rizqiani \& Yulianto, 2020). In addition, the firms also have to use the finesse profession seriously in providing services that the firms can fulfill their professional responsibilities. Quality control is closely related but different from PAPS (Arens, 2005).

\section{Professional Skepticism}

The professional skepticism of a public accountant is needed to make decisions on how much and what type of audit evidence should be collected (Arens, 2008). Furthermore, Hurtt in Haikal (2017) also developed a model as an indicator in measuring the professional skepticism. This model explained at least six main characteristics that a public accountant must have when applying professional skepticism: questioning mind, suspensions of judgment, search for knowledge, interpersonal understanding, selfconfidence, and self-determination.

\section{Peer Review}

Peer review is an examination of quality control procedures related to the accounting, auditing, and accounting offices by a public accounting firm or a 
group of other accountants. Based on the Minister of Finance Regulation Number 17/PMK.01/2008 on Public Accountant Services, the public accounting firm will be the peer review from time to time to ensure that all set standards have been applied to maintain the audit quality results provided by the public accounting firms.

\section{Hypothesis Development}

Quality Control Standards provide guidance for Public Accounting Firms in exercising control over the quality of audit services produced (SPAP, 2011). The relevant element of quality control system associated with the auditors' skepticism is the auditors' professional development in which the Public Accounting Firms must implement a professional quality control policy to provide sufficient assurance that each personnel has sufficient knowledge to fulfill and perform their responsibilities as best as possible (Agoes, 2012). The wider the auditors' knowledge, the more significant the professional skepticism will be (Oktaviani, 2015). In addition to the perception, the work of public accountants will be examined by the Financial Professional Development Center (known as PPPK/Pusat Pembinaan Profesi Keuangan). So, public accountants will more carefully perform the procedures in accordance with the set standards and avoid the sanctions made by the Financial Professional Development Center when audited.

$H_{1}$ : Interaction between quality control system and peer review has a significant effect on professional skepticism

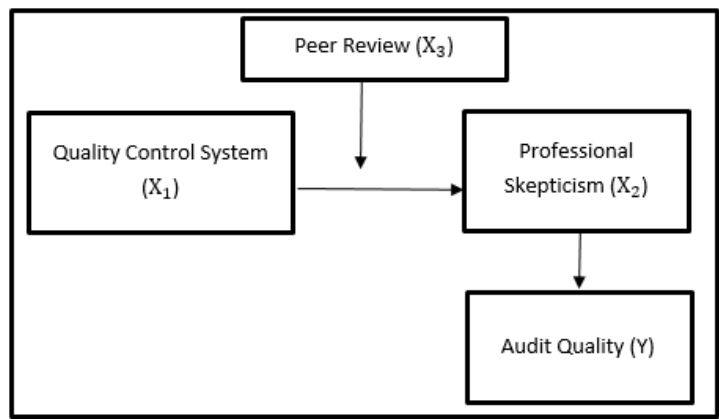

Figure 1. Research Model 
Hafidz Ridloi

In auditing standards, an auditor is required to use professional skepticism when performing an audit. With professional skepticism, the auditor might collect sufficient audit evidence and did not easily accept the explanation or information from an auditee as a basis for detecting the arising fraud. Thus, a high degree of skepticism will result in a better quality. Research conducted by Ananda (2014) shows that skepticism has a positive and significant effect on audit quality. This result is also supported by that conducted by Merici (2016) explaining that professional skepticism has a dominant effect on the accuracy in giving the auditor's opinion.

\section{$\mathrm{H}_{2}: \quad$ Professional skepticism has a significant effect on audit quality}

To engage with the professional audit services, all Public Accounting Firms are obliged to follow and execute the various Public Accountant Professional Standards (PAPS), one of which, the standard providing guidance for Public Accounting Firms in performing the resulted quality control services. These standards are contained in the quality control standards (PAPS, 2011). According to Erdiani (2018), the quality control system partially has a significant effect on audit quality. In addition, the Public Accounting Firms must consider the integrity of their staffs in determining their professional relationship and showing that they are professionally competent, objective, and can carefully and thoroughly maximize their professional skills (SPAP, 2011). In performing the audit procedures, a public accountant should also have the perception that his work will be examined by the Financial Professional Development Center through the peer review procedures.

$H_{3:}$ Interaction between quality control system and peer review has a significant effect on professional skepticism and impact on audit quality

\section{Research Methods}

This study used quantitative data which can be measured on a numerical scale. Meanwhile, the data sources in this study were the primary data 
The effects of quality control system on professional skepticism ...

directly obtained from the original sources for a specific purpose, such as questionnaire.

The population in this study was auditors working at the Public Accounting Firms in Semarang. Meanwhile, the samples were collected using a purposive sampling technique only considering the Public Accounting Firms providing responses. The whole population in this study was taken as the research samples.

The data were collected through questionnaires using a Likert scale with the value of 1 for the lowest and 5 for the highest answers. Instrument validity and reliability tests were conducted in this study. PLS-SEM using WarpPLS program was performed to measure the validity of variable by examining the convergent validity seen from the loading factor value of more than 0.7. The rule of thumb is commonly used to assess the convergent validity with the loading factor value of more than 0.7 for the confirmatory research and between 0.6-0.7 for exploratory research as well as the average variance extracted (AVE) value of greater than 0.5 (Latan and Ghazali, 2012).

Meanwhile, the reliability was tested in two ways: Cronbach's Alpha and Composite Reliability. However, the Cronbach's Alpha will give a lower value. Thus, it is advisable to use the composite reliability to test the reliability of a variable. The rule of thumb commonly used to assess the construction reliability is the Composite Reliability with the value of greater than 0.7 for Confirmatory research and 0.6-0.7 for exploratory research (Latan and Ghozali, 2012).

Audit quality is defined as the probability that a certified public accountant will find and report errors or violations occurring in the client's accounting systems by holding the applicable and relevant auditing standards. The indicators used in this research were: (1) Finding and reporting the clients' errors; (2) Having a good understanding related to the auditees' information systems; (3) Having a strong commitment to complete the audit, (4) Holding the auditing and accounting principles, (5) It is not easy 
Hafidz Ridloi

to believe on information from the auditees, (6) Always be careful in making decisions.

Quality control system is closely related but has differences with the auditing standards. In order to provide assurance, all principles in the auditing standards have to be applied in every audit. The Public Accounting Firm must comply with specific quality control procedures to help CPA Firm consistently and meet the standards in every audit assignment. The indicators used were as follows; (1) Independence, (2) Personnel Assignment, (3) Consulting, (4) Supervision, (5) Hiring, (6) Professional Development, (7) Promotion, (8) Client Acceptance and Sustainability, and (9) Inspection.

The competitors' professional skepticism requires an auditor with 6 main characteristics: questioning mind, suspensions of judgment, search for knowledge, interpersonal understanding, self-confidence and selfdetermination.

Peer review is an examination of quality control procedures of the accounting, auditing, and accounting office by the accounting firms or a group of the other accountants. Peer review in this study is a perception that the work of a public accountant will be examined by the Financial Professional Development Center.

Table 1. Percentage of Questionnaire Responses

\begin{tabular}{lrr}
\hline \multicolumn{1}{c}{ Description } & Number & Percentage \\
\hline Number of CPA Firms receiving the online & 21 & $100 \%$ \\
questionnaire link & 14 & $67 \%$ \\
Number of CPA Firms providing responses & 7 & $33 \%$ \\
Number of CPA Firms not providing responses & 31 & $100 \%$ \\
Number of received responses & 31 & $100 \%$ \\
Number of responses processed as the research & & \\
Samples &
\end{tabular}


The data analysis technique used in this research was the Structural Equation Modeling (SEM) method. This method was conducted with a Variance Based SEM approach or often known as Partial Least Squares (PLS). According to Wold (1982) in Latan and Ghazali (2012), PLS is a powerful analysis method which is not based on many assumptions, for example the data must be normally distributed and not be in large quantity.

Partial Least Square (PLS) is a Structural Equation Modeling (SEM) which is more appropriate to use when compared to the other SEM completion techniques. Equipped with the WarpPLS 4.0 software to analyze the data.

\section{Results and Discussion}

\section{Convergent Validity}

The criteria to meet the evaluation of convergent validity is that the AVE value must be greater than 0.50 (Latan \& Ghazali, 2012). Based on Table 2 above, it can be seen that all variables have met the criteria of convergent validity. The quality control system variable had the AVE value of 0.571 greater than 0.50 and the professional skepticism variable also had the AVE value of 0.583 greater than 0.50 . The audit quality and peer review variables had the values of respectively 0.576 and 0.622 greater than 0.50 . It can be concluded that all used indicators were valid or met the criteria of convergent validity.

\section{Composite Reliability}

Based on table 2 above, it can be seen the value of each variable's composite reliability. The quality control system variable (X1), professional skepticism variable (X2), audit quality variable (Y), and peer review variable (X3) had the values of respectively $0.955,0.944,0.942$ and 0.892 greater than 0.70 (Latan \& Ghazali, 2012). Thus, it can be concluded that all variables used in this study met the criteria required by composite reliability and were considered reliable. 
Hafidz Ridloi

Table 2. Output of Latent Variable Coefficients

JIAFR | 84

\begin{tabular}{lcccc}
\hline & QCS (X1) & SP (X2) & KA (Y) & PR (X3) \\
\hline R-squared & & 0.384 & 0.744 & \\
Adj. R-squared & & 0.340 & 0.735 & \\
Composite reliab. & 0.955 & 0.944 & 0.942 & 0.892 \\
Cronbach's alpha & 0.950 & 0.935 & 0.933 & 0.848 \\
Avg. var. extrac. & 0.571 & 0.583 & 0.576 & 0.622 \\
Full collin. VIF & 1.572 & 5.306 & 3.871 & 1.340 \\
Q-squared & & 0.422 & 0.745 & \\
\hline
\end{tabular}

Model of fit and quality indices

Average path coefficient $(\mathrm{APC})=0.505, \mathrm{P}<0.001$

Average $R$-squared $(A R S)=0.564, P=0.003$

Average block VIF (AVIF)=2.786, acceptable if $<=5$, ideally $<=3.3$

Figure 2. Output of General Sem Analysis Results

Figure 2 above shows that the average path coefficient (APC) value had the index of 0.505 with the P-value of less than 0.001 . Meanwhile, the average R-squared (ARS) index was 0.564 with the P-value $=0.003$. Based on the fit model test criteria, APC and ARS were in accordance with the requirements, because both P-values were less than 0.05 (Latan and Ghazali, 2012). Meanwhile, the AVIF value was 2.786 and also met the criteria of less than 5 . From the description above, it can be concluded that the inner model evaluation was acceptable and could be continued to the next test.

\section{Hypothesis Test}

The results of correlation between variables measured using path coefficient and significance level, were then compared with the hypothesis formulated in chapter two. This study used the significance level of $5 \%$. 
The effects of quality control system on professional skepticism ...

Table 3. Direct Effects

\begin{tabular}{|c|c|c|c|c|c|}
\hline Criteria & Variables & $\begin{array}{l}\text { QCS } \\
\text { (X1) }\end{array}$ & $\begin{array}{c}\text { SP } \\
(\times 2) \\
\end{array}$ & $\begin{array}{l}\text { KA } \\
\text { (Y) }\end{array}$ & $\begin{array}{c}\text { QCS (X1)*PR } \\
\text { (X3) }\end{array}$ \\
\hline \multirow{3}{*}{ Path coefficients } & QCS (X1) & & & & \\
\hline & $\mathrm{SP}(\mathrm{X} 2)$ & 0.324 & & & -0.329 \\
\hline & $\mathrm{KA}(\mathrm{Y})$ & & 0.863 & & \\
\hline \multirow{3}{*}{ P-values } & QCS (X1) & & & & \\
\hline & $\mathrm{SP}(\mathrm{X} 2)$ & 0.170 & & & 0.152 \\
\hline & $\mathrm{KA}(\mathrm{Y})$ & & $<0.001$ & & \\
\hline \multirow{3}{*}{$\begin{array}{l}\text { Effect sizes for } \\
\text { path }\end{array}$} & QCS (X1) & & & & \\
\hline & $\mathrm{SP}(\mathrm{X} 2)$ & 0.190 & & & 0.194 \\
\hline & $\mathrm{KA}(\mathrm{Y})$ & & 0.744 & & \\
\hline R-squared & & & 0.384 & 0.744 & \\
\hline
\end{tabular}

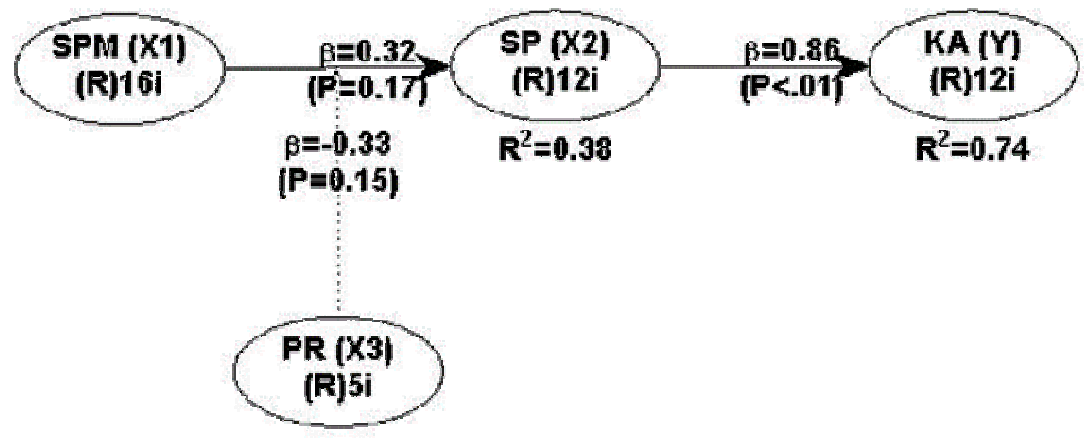

Figure 3. Results

The effect of interaction between Quality Control System and Peer Review on Professional Skepticism

Based on the research results, it was found that the quality control system implemented in the public accounting firm did not affect the auditors' professional skepticism proven with the P-value of 0.170 more than 0.05 . 
Hafidz Ridloi

Meanwhile, the interaction between quality control system and peer review also did not affect in determining the auditors' professional skepticism level proven with the P-value of 0.152 greater than 0.05 . It means that the perception of peer review did not moderate in this research model.

According to Oktaviani (2015), professional skepticism is influenced more by the auditors' ethics, working experience, competence, and professionalism. Thus, it can be concluded that no matter how good it is implemented, the quality control system will not increase the skepticism if auditors did not have ethics, experience, sufficient competence and professionalism.

\section{The effect of professional skepticism on audit quality}

Based on the research results, it was found that the auditors' professional skepticism had a significant effect on the resulted audit quality proven with the P-value of $<0.001$ less than 0.05 . This result was in accordance with that of the previous research conducted by Merici (2016) and Ananda (2014) stating that professional skepticism had a significant effect on audit quality.

The results of this study indicate that the value of path coefficient or beta $(\beta)$ was 0.863 . It means that the higher the auditors' skepticism level, the better the audit quality will be resulted. With the R-squared value of 0.744 , it means that the auditors' professional skepticism level affected the audit quality by $74 \%$.

Referring to the figures above, it can be said that professional skepticism quite greatly affected audit quality. It means that it is imperative for an auditor to have a better skeptical attitude on the audit procedures and be able to provide accurate and accountable opinions. Thus, the audit results can be a reference for the economic decision makers.

\section{The effect of interaction between quality control system and peer review on professional skepticism and its impact on audit quality}

Based on the research results, it was found that the quality control system did not affect audit quality through the auditors' professional skepticism 
proven with the beta value ( $\beta$ ) of 0.279 with the P-value of 0.158 . Meanwhile, the interaction between quality control system and peer review did not affect audit quality through the auditor's professional skepticism proven with the beta value $(\beta)$ of -0.284 and $P$-value of 0.159 . Its means that peer review did not moderate in this research model.

JIAFR | 87

This study did not examine the effect of quality control system on audit quality, because based on the research conducted by Fauji, Sudarma, and Achsin (2015), it was stated that quality control system had a simultaneous effect on audit quality. Another study conducted by Pramana (2014) also stated that quality control system and time budget pressure had a significant effect on audit quality.

The results of this study indicate that quality control system implemented by the public accounting firms did not guarantee increasing the auditor's professional skepticism to obtain good audit quality. Skepticism is an attitude that must be attached to each individual from auditor to be more observant and careful in looking for the audit evidence supporting the audit results. Meanwhile, quality control system is implemented institutionally or organizationally at the Public Accounting Firms to ensure that the performed procedures in providing audit services are in accordance with the applicable standards.

\section{Conclusion}

The interaction between quality control system and peer review did not affect the auditors' professional skepticism. It means that no matter how good the quality control system is implemented, it will not affect the public accountant's skepticism level. Auditor's professional skepticism had a significant effect on the resulted audit quality. The higher the skepticism, the better the audit quality is made by the public accountants. The interaction between quality control system and peer review did not affect audit quality through the auditor's professional skepticism. Auditor's professional skepticism was more dominantly influenced by the other factors than the quality control system and indirectly did not affect the audit quality made by 
Hafidz Ridloi

the public accountants. To maintain the audit quality made by the public accountants, the Public Accounting Firms in Semarang are required to improve the personnel's competence, experience, and professionalism in performing the audit assignments, thus, the professional skepticism of the related personnel can be properly maintained.

In addition, the public accounting firms in Semarang are required to strengthen the implemented quality control system to encourage the competence, experience, and professionalism of the related personnel to increase and it is expected that the auditors' professional skepticism can be well maintained. The scope of this research is only limited to a relatively small number of public accounting firms in Semarang. Thus, further researchers can expand the research scope to generalize the results to all Public Accountants and Public Accounting Firms throughout Indonesia.

\section{References}

Agoes, S. (2012). Auditing: Petunjuk Praktis Pemeriksaan Akuntan oleh Akuntan Publik (4 ed., Vol. 1). Jakarta: Salemba Empat.

Arens, e. a. (2005). Auditing and Assurance Service an Integrated Approach (10 ed.). USA: Pearson Prentice Hall.

Arens, e. a. (2008). Auditing dan Jasa Assurance Pendekatan Terindikasi (12 ed., Vol. 1). Jakarta: Erlangga.

Agriyanto, R., Rohman, A., Ratmono, D., \& Ghozali, I. (2016). Accrual Based Implementation: An Approach for Modelling Major Decisions. Risk Governance \& Control: Financial Markets \& Institutions, 6(4), 531-539.

Ananda, R. (2014). Pengaruh Skeptisisme Profesional, Kepatuhan pada Kode Etik dan Independensi terhadap Kualitas Audit. Jurnal Akuntansi, 2(3), 1.

Bustami, A. (2013). Pengaruh Independensi, Akuntabilitas dan Profesionalisme Auditor terhadap Kualitas Audit. Repository UIN Syarif Hidayatullah.

Erdiani, N. (2018). Pengaruh Sistem Pengendalian Mutu Dan Time Budget Pressure Terhadap Kualitas Audit. Fakultas Ekonomi dan Bisnis, UMSU. 
Fauji, L., \& dkk. (2015). Penerapan Sistem Pengendalian Mutu (SPM) Dalam Meningkatkan Kualitas Audit. Jurnal Akuntansi Muti Paradigma, 6(1).

Haikal, F. M. (2017). Pengaruh Kompetensi, Independensi, Dan Skeptisisme Profesional Auditor Terhadap Pendeteksian Fraud. Fakultas Ekonomi dan Bisnis, Universitas Lampung.

Institut Akuntan Publik Indonesia. (2011). Standar Profesional Akuntan Publik Jakarta: Salemba Empat.

Institut Akuntan Publik Indonesia. (2020). Directory Kantor Akuntan Publik dan Akuntan Publik 2020. Jakarta: IAPI.

Junusi, R. (2020). COSO-based internal control: efforts towards good university governance.Journal of Islamic Accounting and Finance Research, 2(1), doi:http://dx.doi.org/10.21580/jiafr.2020.2.1.4773

27-50.

Latan, H., \& Ghazali, I. (2012). Partial Least Squares Konsep, Teknik dan Aplikasi Menggunakan Program Smart PLS 2.0 M3. Semarang: Badan Penerbit UNDIP.

Merici, A., Cresensia, \& dkk. (2016). Pengaruh Skeptisisme Profesional, Pengalaman Audit, Keahlian Audit, Independensi, Dan Kompetensi Terhadap Ketepatan Pemberian Opini Auditor. Jurnal Riset Mahasiswa Akuntansi, 4(1).

Oktaviani, N. F. (2015). Faktor-faktor yang Mempengaruhi Sikap Skeptisisme Profesional Auditor di KAP Kota Semarang. Fakultas Ekonomi, UNNES.

Pramana, R. (2014). Pengaruh Sistem Pengendalian Mutu dan Time Budget Pressure terhadap Kualitas Audit. Fakultas Ekonomi, Universitas Widyatama.

Renianawati, R., \& et al. (2016). Pengaruh Sistem Pengendalian Mutu dan Continuing Profesional Development Terhadap Kualitas Audit. Repository Univestias Islam Bandung, 2(2).

Rizqiani, D., \& Yulianto, A. (2020). The implementation of sharia audit process, implication of sharia regulatory and human resource aspects. Journal of Islamic Accounting and Finance Research, 2(1), 5168. doi:http://dx.doi.org/10.21580/jiafr.2020.2.1.5220. 
Hafidz Ridloi

Tim CNN Indonesia. (2018, September 26). Kasus SNP Finance, Dua Kantor Akuntan Publik Diduga Bersalah. retrieved on Januari 29, 2020, from CNN Indonesia:

https://www.cnnindonesia.com/ekonomi/20180926072123-78-

JIAFR | 90 333248/kasus-snp-finance-dua-kantor-akuntan-publik-didugabersalah 